\title{
Ideas for Increasing Creativity in Teaching by Using the Art of Language to Make Relatively Boring Classes More Entertaining
}

\author{
Shuyuan Liu* \\ Jserra catholic High school, San Juan Capistrano,92675, California, the United States \\ ${ }^{*}$ Corresponding author. Email: shuyuan.liu@jserra.org
}

\begin{abstract}
Education has always been a highly debated and controversial topic among experts. Law study in all studied areas was especially hard because the law is serious and sometimes cannot be joked about. There are limited ways to make it more attractive to learners, and there are almost no special tricks in law study, which makes students easily countering difficulties in law studies. This paper focuses on a law study teacher named Luo Xiang, who was made extremely famous on the Chinese internet with his teaching of law studies. And I offer an outline of his teaching styles on law studies, as education needs to follow with time and fashion to keep the students' attention. And the body paragraph of this paper uses cited transcripts. Various works are cited with examples from one of Professor Luo's MOOC videos to analyze the teacher's teaching methods in Language, pitch and tone when he speaks and teaches. The example applications were created to better illustrate his teachings to his fellow students who watch his uploads. And I investigate why his teaching being so fascinating to young people. The teacher mainly teaches in MOOCs, and all his teaching is on video, less interactive may see but only on bullets screens which are lines and lines of word flies through the screen that viewers typed in. Most of these bullet screens were the students' expressions of emotion presented on them. However, his teachings languages are interesting to examine and dig in for further research and study.
\end{abstract}

Keywords: MOOCs, Live Examples, Bullet Screens, Pitch, Tone.

\section{INTRODUCTION}

Teaching has gone over thousands of years of history, but teachers' primary teaching mode is transferring information to students. And students had to remember them to make sure all these knowledges will not be lost in the wastebasket of history, letting students listen and take notes in class, especially in some not very interesting or entertaining classes, which is a hard task for teachers. Also, attracting students' attention has become a popular debate among researchers and teachers, because for sure, teachers would not want their students to sleep in class because of dull content. Not only do students get no benefits from it, but also teachers cannot benefit from it. As time progresses, the teacher's teaching methodologies also progress because nobody wants to drop behind. This is surely a long process, as many teachers developed diverse teaching skills to draw students' attention to them and the class material they were transmitting. Some by simply Language, some uses life lab or experiments, and some teachers use their fantastic acting skills to make students laugh. There is just a lot for education experts to dig down as human has infinity potentials. This paper will take on analyzing how the art of Languages such as humor and jokes are represented in different ways in the study of law.

\subsection{Law Study}

Law study is quite boring, and except you will become a government official or law worker like a judge or lawyer, it was not necessary. Dr. Audsley pointed out why people are choosing law study as a prerequisite for a future career. She claimed that law study gave people great competitive power in getting jobs because of its massive transferable skills. The law worker's high salaries also attract people to step into this field [1]. In the People's Republic of China, the law study is crucial for the people who intended to be law workers. Even people who do not want to be law workers also need to learn some common law basics, preventing them from breaking the law and getting fined. Before they get their 
Lawyer or Judge license, the Law students need to pass a law test to get their jobs as law workers. Law study is a relatively hard and boring subject, and people without courage or persistence cannot take on the pressures that lay on their shoulder, and some people even chooses to drop off these studies. And a specific person in China's teaching system had turned the tide of the quite boring education phenomenon.

\section{STUDIED MODE AND STUDIED TEACHER}

According to Dr. Halili, the education minister of Malaysian Datuk Seri Idris Jusoh talked about the new topic of education 4.0 of included more knowledge, industry, and humanity [2]. Some teachers had recently applied this idea. Luo Xiang, a postgraduate degree in penology teacher from Beijing university, started a small earthquake in the law study area by moving his main activity on an entertainment-based app Bilibili Douga in 2018. As he started his channel, he starts posting MOOCS classes. His channel began skyrocketing, helping him become one of the most influential characters on that platform and has nothing to do with pure entertainment. He breaks through 10 million subscribers in 2020. Many of his memes being created by photos shopping his face or screenshot his lessons and adding random words on them. This act made him even more popular, attracted more people to watch his classes, and did help many students pass their law tests in both pressure and pleasure. How exactly did his Language prove attractive to people in almost all age groups? It mainly depends on three parts that go along with small transcripts from his classes.

\subsection{MOOCS Classes}

It has been debated that education should be applied with technologies. Dr. Juniu made a point about integrating technologies with education, and teachers can only post information that students needed online, and students can reorganize the knowledge in their characteristics. This was called "technological pedagogical content knowledge" [3]. Professor Luo's main teaching mode is MOOCs, or Massive Open Online Courses, which are examples of this type of study, which is a quite unstable teaching mode without a teacher's supervision and guidance and provided equal chances of getting a higher quality of education. According to Dr. Christensen, most of the students of MOOCs were well educated and young and employed people from a developed country, and students from developing countries that taken MOOCs are for advancing jobs and satisfying their curiosity [4]. Because of fewer supervisions and guidance from a teacher, students attend the MOOCs, always having a low completion rate and high dropping rate. According to the studies done by Dr. Rivard, over 90 percent of registered students dropping out of their classes [5]. Even though Professor Luo's class has few interactions with students, and his students who watched his video were from all ages, postgraduate college students are learning laws for advancing backgrounds. There is high school, junior high even primary school students who watch his video for entertaining learning. Most of the student's feelings were typed in the bullet screens on his videos. MOOCs indeed make Professor Luo's class more creative because the convenience of MOOCs can compress a large number of data sets into relatively short videos. With large data, bigger experiments are easier to perform, as Dr. Reich implied [6]. There are rarely people dropping off from professor Luo's classes and even watching his videos daily as entertainment. But what makes Professor Luo's classes being so fascinating to young people? The paper will take language analytics upon a MOOCs video from Professor Luo named: Stealing and eating my poisonous peanuts, is that count as negligent homicide? Luo Xiang Law talk [7].

\subsection{Common Languages}

There are many difficult terminologies in both science and law studies that students must encounter problems with when figuring out themselves, even after reading all the definitions. The unstable MOOC platform made its effectiveness even more unpredictable. Culatta claimed that if people cannot talk about difficult concepts consistently, then students will never understand them [8]. In one of Professor Luo's classes, he explained a concept named "crime of Negligent homicide" as he mentioned the question in his previous video. Jiang San owns a bike with poisoned peanuts stored in the back seats that he brought to extinguish the mouse crisis. Zhang San steals his bike, and without knowing that the peanuts are poisonous, Zhang ate them and died of being poisoned. one of Professor Luo's most often used tricks of common languages is jokes. There has never been a clear definition of Jokes, and as Dr. Attardo claimed, Jokes are rather blurry concepts and hard to find enough commons, but the only common we know about jokes is that they were all funny in some ways [9]. This is an action of effort to work on the class phenomenon, as according to Davis, it is important to create a passionate atmosphere for students if they want to learn with the best they got [10]. He explains this is a hard question as to how to spend the term negligent, and he says according to the law of crime is pended in two standards: firstly, being overly confident in judgment or being careless. He explained that being overly confident means a doctor takes a shot for penicillin for the patient without testing allergic reactions out of confidence and killing the patient, which caused medical malpractice. One of the most famous examples is the death of Michael Jackson. Dr. Norman implied that the definition of medical malpractice is an act in which nurses or doctors violate the medical standard resulting in medical harm to the 
patient [11]. Being careless is just like turning in a basement parking lot and accidentally crushes a drunken man to death, which most people would have this mistake. Dr. Mancke said this is why the vehicle code was established, in when people do not violate this code could prevent numbers of involuntary manslaughter [12]. Teaching in common languages does not have to be how common it is. The most important thing is it must be understandable, or else it is meaningless. Professor successfully using his style personalized the teaching of law and called it a success.

\subsection{Risen Pitch and Tone}

Professor Luo's other significant when he teaches is constantly changing pitch. His pitch moves go high and low like a spring in motions. His use of speech tone will be shown by a cited transcript of his lectures, when he was teaching about the "law of result of foreseen the obligation":

As you are driving $\wedge$, seen people ahead,

You should slow down $=$ but you didn't^ .

And you ran him over.

This violates the result of avoiding the obligation

Giving a shot of penicillin to the patient

$\mathrm{You}^{\wedge}$ should do a skin test

But $^{\wedge}$ you didn't,

And he is ${ }^{\wedge}$ a dead $\operatorname{man}^{\wedge}$

You said that I forgot ${ }^{\wedge}$ about it.

You should foresee it, but you didn't.

As professor Luo talks along, we can see his pitches frequently raised when he talks to class, and he rarely had to stop his pace of teaching, which had made his teaching more consistent. And sometimes, when he comes to the second personal pronoun, he strengthens his speaking tone to mention that this is serious. There is another example to provide more proof of his speaking. And more teaching features will be shown in the transcript, which is also from the same video he teaches.

\section{As Zhang San driving ${ }^{\wedge}$,}

He saws a wasp's nest ${ }^{\wedge}$.

This $^{\wedge}$ makes him reminisce about his happy time childhood by poking the wasp nest ((or is it?))

Makes him wants to brings this:nest down and take the honey inside ((I don't think wasp nest has those...))

With this thought, he brought gears and equipment.

When it is eleven o'clock am, he removes the entire ${ }^{\wedge}$ nest.

And warped it around with his clothes.
And put it into his car,

While he is still dealing with the wasp.

His girlfriend is tried to maintain $\operatorname{order}^{\wedge}$ around.

Saying: Ah- no $^{\wedge}$, no $^{\wedge}$, don't look at it, it is dangerous ${ }^{\wedge}$, ((waving hands))

Don't look at children; it is dangerous! These are wasps. ((waving hands))

She maintained order well,

Eventually, the nest was removed and brought back and got roasted ((I don't know about is that how to deal with wasps? ))

$\mathrm{But}^{\wedge}$ this is not ended; as Li Si walked past the tree,

$\mathrm{Un}^{\wedge}$ :fortunately for $\mathrm{Li} \mathrm{Si}$, he gets $\operatorname{stung}^{\wedge}$ by the wasps((sudden lowered and lightened tone)),

And he^ died.

Why?

Zhang San already had the entire nest moved away,

But what he didn't^ think about is,

Most of the wasps already went to work ${ }^{\wedge}$ at $7 \mathrm{am}^{\wedge}$ !

During the mid of the day, they returned,

The returned wasps surprisingly found their nest missing $\wedge$ !

Where $^{\wedge}$ is my house ${ }^{\wedge}$ ? Where ${ }^{\wedge}$ is my house ${ }^{\wedge}$ ? (Swinging his hand)

And they found Li Si passed by,

They thought he might be the nest or the one that demolished the nest ((pointing his hands towards the camera))

In the end, an entire hoard of off-work wasp had Li Si stung to his death. ((pointing gesture with waving hand))

Li Si was transferred to the hospital but still died of wasp poison.

As going through the transcript, not only did the tone and pitch changes had been more specified, and there is something more to Professor Luo's teaching, which is Gestures. When he gets excited, his hand usually points at the camera to students watching or waving his hand for further exaggeration and demonstrations. But this would not be specified in the paper. In the transcript, Professor Luo speaks with enthusiasm changing his tones pitches tried to create a proper scene phenomenon that you can feel or know what's happening. Typically, most teachers tend to speak to their students in a superior and more serious tone to show their authority to a class. Most of the time, they use more professional languages. This is understandable, but it draws further the distance between students and teachers, and too professional Language 
could create difficulties for students to understand. Professor Luo, however, is willing to put down the teacher's superiority and have himself blended among the students and their pop cultures included their interests. As the transcript told me that he uses various pitch types and easily understands languages to talk about terminologies, Dr. Nencheva expressed her opinion about how pitch works in education. She claimed that pitch in speaking forms the module of children's attention, reflection speed, and interaction skills [13]. Professor Luo's speaking skills, alongside his facial expressions in training, expressed his personality to his students and audiences positively and increased his students to be autonomous learners and be interested in learning and absorbing new knowledge. Making it another success in his career.

\subsection{Hilarious Examples of Actual Use of Law}

If there is more thing rather than Professor Luo's teaching languages type and speaking pitches is his examples in the application of law study. How to fix the gap between thinking and reality is a debated question. Dr. Løvlie suggested that using examples in moral education can bridge the gap between thinking and reality and had the concepts make more sense to learners [14]. These examples were classical humor to watch. Professor Sahin from Keykubat university made a point about the term humor, including three types of humor: selfenhancing humor mostly used for maintaining selfesteem, affiliation humor mainly used in communication to make others laugh, and aggressive humor mainly used as language critics on other people [15]. In this case, Professor Luo uses affiliation humor. This is how Professor Luo's idea of teaching of consisting funny examples and jokes, even online memes, into his teaching. Professor Luo provided lots of hilarious examples of his law teachings as the made-up character Zhang San always being the "victim" under the Language of Professor Luo by mainly being the man that breaks the law or creating incidents. In this video, he provided another example of accidental homicide which listed above as a transcript: Zhang San saws a wasp nest, reminiscent of his childhood of picking bones with wasps by poking their nest; he brought equipment and removed the entire nest from the tree and trying to do some cooking with homey inside if there is any, his girlfriend maintains the surrounding well, and did all they could preventing wasp from escaping the nest. But as they had left, Li Si walked past down the tree and was targeted by the returning wasp that found their nest missing thinking he is the one who removed their nest and stung him to death. Because Zhang San had done all he could to prevent any accident, he did not know that a wasp would return to their nest while people are passing. While telling this part, Professor Luo exclaimed about his thoughts on this example, claiming that before Zhang San tries to remove the nest, he already observed no hoard nearby. His girlfriend had kept all the people away, and he warped his clothes and clothes around the next to prevent wasp escaping, but he never thought that the wasps would return and eventually caused Li Si's death. Eventually, he added on: "the wasps were even more hard-working than me, they went out at 6 am and returned at $6 \mathrm{pm}$, and as they returned found their nest missing, how would they feel?" eventually in the example, Zhang San's action is not considered as guilty. Since this is an unpredictable accident, the final sentence only requires him to compensate for the loss of Li Si's family. And by the end of this example professor also indicates the importance of law is only needed when the situation requires, or else it will be making things too complicated and timeconsuming.

\section{CONCLUSION}

This review paper goes over three teaching styles of Law professor Luo's: his appropriate uses of common languages explaining difficult concepts, his often raised or lowered pitch and hand gestures to create different language effects, and his examples of how to break laws created by himself which will always let his students learned them in a while cannot stop from laughing. His common languages help students better understand the materials. Even though they were not law professionals or even underaged students, they could easily understand and be interested in learning. His raised pitch increases the humor in the teaching environment and loses the tension between teachers and students to bring them closer. And finally, his examples that are the point famous also help better comprehend the materials apply the laws into stimulations and provide a reason why they ever exist. His teaching skills need quite an amount of patient. His methods are effective and can be seen as how famous he had turned out, modern teachers are developing their teaching style, but let you students laugh for a second, to loosing up their tense mind is also good for their development.

\section{REFERENCES}

[1] Audsley S. M, 7 reasons to study Law, keystone Law studies, August 19, 2020. DOI: https://www.lawstudies.com/article/7-reasons-tostudy-law/.

[2] Halili, S.H., "Technological advancements in education 4.0." The Online Journal of Distance Education and e-Learning 7.1 (2019): 63-69. DOI: http://tojdel.net/journals/tojdel/articles/v07i01/v07i 01-08.pdf.

[3] Juniu, S., "Pedagogical uses of technology in physical education." Journal of Physical Education, Recreation \& Dance 82.9 (2011): 41-49. DOI: https://www.tandfonline.com/doi/abs/10.1080/0730 3084.2011.10598692? journalCode=ujrd20. 
[4] Christensen G, Steinmetz A, Alcorn B, et al. The MOOC phenomenon: Who takes massive open online courses and why?[J]. Available at SSRN 2350964, 2013.

DOI: https://papers.ssrn.com/sol3/papers.cfm?abstract_id $=2350964$.

[5] Rivard, R., "Measuring the MOOC dropout rate." Inside Higher Ed 8 (2013): 2013. DOI: https://immagic.com/eLibrary/ARCHIVES/GENE RAL/GENPRESS/I130308R.pdf.

[6] Reich, J., "Rebooting MOOC research." Science 347.6217 (2015): 34-35. DOI: https://www.science.org/doi/abs/10.1126/science.1 261627.

[7] Xiang.L., Stealing and eating my poisonous peanuts, is that count as negligent homicide? Luo Xiang Law talk 2021-05-07 https://www.bilibili.com/video/BV16h411m7NG.

[8] Richard C., what are you talking about? The need for common Language around personalized learning. Educause, March 21, 2016. DOI: https://er.educause.edu/articles/2016/3/what-areyou-talking-about-the-need-for-common-languagearound-personalized-learning.

[9] Attardo, S, and Jean-Charles C., "Jokes as a text type." (1992): 165-176. DOI: https://www.degruyter.com/document/doi/10.1515/ humr.1992.5.1-2.165/html.

[10] Lauren C. D., creative teaching and teaching.creativity: how to foster creativity in the class room? Psych learning curve, December 17 2018. DOI: http://psychlearningcurve.org/creativeteaching-and-teaching-creativity-how-to-fostercreativity-in-the-classroom/.

[11] Norman, Gail A. Van, and Joel S. Rosen. "Criminal Homicide Versus Medical Malpractice: Lessons from the Michael Jackson Case and Others." Pediatric Sedation Outside of the Operating Room (2021): 813-825. DOI: https://link.springer.com/chapter/10.1007/978-3030-58406-1_43.

[12] Mancke, John B. "Homicide by Vehicle in Pennsylvania: A Question of Meaning and Constitutionality." Dick. L. Rev. 85 (1980): 391. DOI: https://heinonline.org/HOL/LandingPage?handle $=\mathrm{h}$ ein.journals $/$ dlr85\&div $=29 \&$ id $=\&$ page $=$.

[13] Nencheva, M. L., Elise A. P., and Casey L., "The moment-to-moment pitch dynamics of childdirected speech shape toddlers' attention and learning." Developmental Science 24.1 (2021): e12997.

DOI:

https://onlinelibrary.wiley.com/doi/epdf/10.1111/d esc. 12997.

[14] Løvlie, L., "The uses of example in moral education." Journal of Philosophy of Education 31.3 (1997): 409-425. DOI: https://onlinelibrary.wiley.com/doi/abs/10.1111/14 67-9752.00065.

[15] Şahin, A., "Humor Use in School Settings: The Perceptions of Teachers." SAGE Open 11.2 (2021): 21582440211022691.

DOI: https://journals.sagepub.com/doi/full/10.1177/2158 2440211022691. 